\title{
THE FATE OF GONOCOCCI IN POLYMORPHONUCLEAR LEUCOCYTES
}

\author{
P. J. WatT \\ Bacteriology Department, Wright-Fleming Institute, \\ St Mary's Hospital Medical School, London
}

HUmaN volunteers can be readily infected with gonococci (Mahoney et al., 1946; Kellogg et al., 1963), but attempts to reproduce the infection in laboratory animals have failed (Hill, 1944). A possible explanation is that man lacks some defence system that is responsible for the destruction of gonococci in immune species. Since gonococci are reported to survive and multiply within polymorphs (Smith, 1968), it might be that gonococci grow in human polymorphs, but are destroyed by the cells of laboratory animals. The work of Zeya and Spitznagel (1968) suggests a possible mechanism for such a situation. These workers resolved the cationic antibacterial proteins from rabbit polymorph lysosomes into five subfractions; each subfraction showed substantial selectivity in its antibacterial action against several pathogenic organisms. It may be suggested that the polymorphs of laboratory animals contain a cationic protein fraction with high activity against gonococci and that this fraction is absent from human cells. To test these propositions, human polymorphs were studied in parallel with those from the guinea-pig, an animal resistant to gonococcal infection (Torrey, 1908), to compare their intracellular killing efficiency and cationic protein activity against gonococci.

\section{MATERIALS AND METHODS}

Neisseria gonorrhoeae test strains. The strains of $N$. gonorrhoeae used-G9, G11 and G34-were identified as Gram-negative, oxidase-positive cocci that fermented dextrose but not maltose or sucrose. The organisms were freshly isolated and stored in a freeze-dried state after the single subculture needed to ensure purity. The techniques used in the culture and enumeration of gonococci will be described by A. A. Glynn and M. E. Ward (to be published). The contents of an ampoule were cultured on the medium of Amies and Garabedian (1967) without added antibiotics, and the overnight growth was subcultured in flasks containing dextrose starch agar (Difco) overlaid with broth prepared to the same formula but without the agar. After incubation for $3 \mathrm{hr}$ at $37^{\circ} \mathrm{C}$ in a shaking waterbath, the flasks contained about $10^{9}$ logarithmic-phase gonococci per $\mathrm{ml}$ of broth. Viable counts were performed with automatic syringes to prepare serial ten-fold dilutions in 1 per cent. Proteose Peptone no. 3 (Difco) in physiological saline, and $0 \cdot 1-\mathrm{ml}$ volumes were then spread over the surface of plates of Amies and Garabedian medium without antibiotics. Plates were incubated for 2 days at $37^{\circ} \mathrm{C}$ in sealed tins without added $\mathrm{CO}_{2}$ and then counts were made with an electronic colony counter. Counts are expressed as the $\log _{10}$ number.

Polymorphonuclear leucocytes. Polymorphs were obtained from guinea-pig peritoneal exudates induced by the injection of $5 \mathrm{ml}$ of 20 per cent. (w/v) "Lab-Lemco" (Oxoid) $5 \mathrm{hr}$ previously; $50 \mathrm{ml}$ of Dulbecco's phosphate-buffered saline (Oxoid) at $p \mathrm{H} \mathrm{7.3}$ was injected 
into the peritoneal cavity and the aspirated cells were washed once in the same buffer. The preparation contained $>\mathbf{9 0}$ per cent. polymorphonuclear leucocytes. Human polymorphs for use in phagocytosis experiments were obtained from samples of blood from one man throughout this study. The polymorphs were separated from the red cells by sedimentation with dextran (Dextraven 110, Fisons Ltd) according to the method of Martin and Green (1958). The large numbers of cells required for the preparation of cationic proteins were obtained from infected peritoneal exudates of patients undergoing dialysis treatment for renal failure.

Procedures for the study of phagocytosis and intracellular killing. The technique used was a modification of that described by Craig and Suter (1966). A suspension of $2 \times 10^{7}$ polymorphs in $2 \mathrm{ml}$ of medium 199 (Glaxo) containing 10 per cent. fresh homologous serum was pipetted into glass petri dishes of 2 in. $(5 \mathrm{~cm})$ diameter. The dishes were incubated at $20^{\circ} \mathrm{C}$ for $30 \mathrm{~min}$., during which time the polymorphs settled and adhered to the glass. The supernatant fluid containing red cells and lymphocytes was removed and $2 \times 10^{8}$ gonococci in $2 \mathrm{ml}$ of medium 199 plus 10 per cent. fresh homologous serum were added. After incubation at $37^{\circ} \mathrm{C}$ for $30 \mathrm{~min}$. (guinea-pig polymorphs) or $45 \mathrm{~min}$. (human polymorphs), extracellular bacteria were washed off the adherent polymorphs by gentle flooding with two 3-ml volumes of warm " 199 " medium at $37^{\circ} \mathrm{C}$. Polymorphs and cell-associated gonococci were washed off the glass by forcibly pipetting five $2-\mathrm{ml}$ volumes of medium 199 on to the cells, and sedimented by centrifuging at $250 \mathrm{~g}$ for $5 \mathrm{~min}$. The cells were resuspended in $1 \mathrm{ml}$ of medium 199 containing 10 per cent. heat-inactivated serum and distributed in $0 \cdot 2-\mathrm{ml}$ volumes in 2-ml plastic vials (Stayne Laboratories). The vials were incubated at $37^{\circ} \mathrm{C}$ in a shaking waterbath and at timed intervals the total number of viable gonococci was determined after rupture of the polymorphs by incubation in 5 per cent. saponin at $37^{\circ} \mathrm{C}$ for $15 \mathrm{~min}$.

Preparation of cationic proteins. Polymorph granules were prepared by the method of Chodirker, Bock and Vaughan (1968) and cationic proteins by fractional ethanol precipitation of acid extracts of the granules (Zeya and Spitznagel, 1966). The cationic proteins were redissolved in distilled water and dialysed overnight against changes of distilled water. Although the human preparation was freely soluble in $0.1 \mathrm{~N}-\mathrm{HCl}$, only 6.5 per cent. was soluble in distilled water; the insoluble fraction was discarded. The proteins were then diluted to a concentration of $500 \mu \mathrm{g}$ per ml in $0.01 \mathrm{M}$ lactate buffer at $p \mathrm{H} 5.6$ and stored frozen at $-20^{\circ} \mathrm{C}$.

Bactericidal action of cationic proteins. Logarithmic-phase cultures containing about $10^{9}$ gonococci per $\mathrm{ml}$ were diluted 1 in 500 in $0.01 \mathrm{M}$ lactate buffer at $p \mathrm{H} 5.6$, and further ten-fold dilutions were made into a buffered control solution and into buffer containing human or guinea-pig cationic protein at a concentration of $50 \mu \mathrm{g}$ per ml. Viable counts were performed at intervals of $5,10,20$ and $40 \mathrm{~min}$.

Analytical methods. Total protein was estimated by the method of Lowry et al. (1951) with lysozyme as a standard; RNA was determined by the Bial reaction for pentoses (Dische and Swartz, 1937); lysozyme by the method of Shugar (1952); $\beta$-glucuronidase by the method of Talalay, Fishman and Huggins (1946), and acid phosphatase by the method of Bessey, Lowry and Brock (1946).

\section{RESULTS}

The survival rates of gonococci within guinea-pig polymorphs are indicated in fig. 1; each line represents the average of three experiments. All three strains of Neisseria gonorrhoeae were rapidly killed by the polymorphs; their half-lives lay between 5 and $10 \mathrm{~min}$., measured over the first $20 \mathrm{~min}$. of the experiment. Less than 1 per cent. of gonococci survived at $100 \mathrm{~min}$; the experiments were not continued beyond this level because Gram-stained smears then showed the presence of occasional extracellular gonococci together with a few mononuclear cells containing bacteria. 
In experiments with human polymorphs, $80-85$ per cent. of the gonococci were killed in the 1st $\mathrm{hr}$, but there was little killing over the next $3 \mathrm{hr}$ and strain G34 even began to multiply (fig. 2). Therefore, it might be that surviving gonococci owe their continuing viability to their ability to resist intracellular destruction, but other possibilities had to be excluded. The polymorphs that

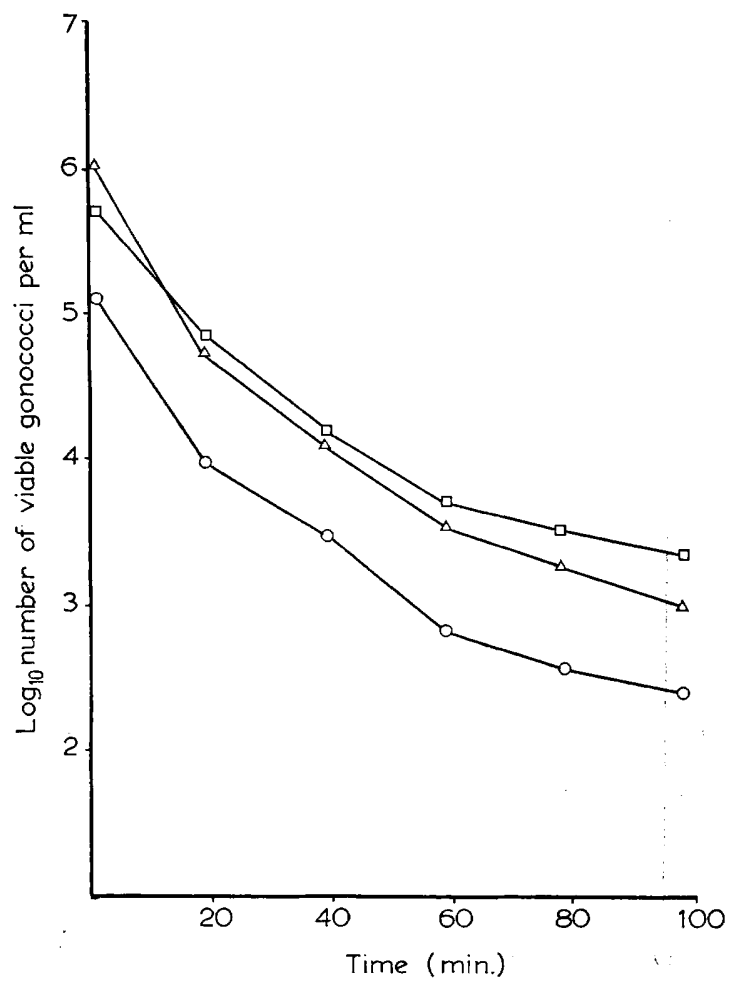

FIG. 1.-The survival rates of three freshly isolated strains of $N$. gonorrhoeae after phagocytosis by guinea-pig polymorphs in vitro. Each line represents the average of three experiments. Gonococci multiplied slowly in the mixture of medium 199 with 10 per cent. heat-inactivated serum that was used to suspend the polymorphs. $\triangle-\triangle$ strain G9; $\square-\square$ strain G11; $\bigcirc-O$ strain $\mathrm{G} 34$.

had phagocytosed gonococci remained active when examined by phasecontrast microscopy; this makes it unlikely that the gonococci survived primarily in polymorphs damaged by the bacteria. Examination of Gram-stained smears showed that only occasional gonococci appeared to be extracellular, although it is possible that some cell-associated gonococci remain outside the polymorph membrane. Thus, experiments were done to determine the relative numbers of viable gonococci that remained within the polymorphs.

Penicillin has no effect on bacteria inside polymorphs (Holmes et al., 1966) and this allows a distinction to be made between intracellular and extracellular persisters. The effect of adding penicillin at a concentration of $1 \mu \mathrm{g}$ per $\mathrm{ml}$ to the preparations of phagocytosed gonococci is also recorded in fig. 2; the 
antibiotic was subsequently destroyed by incubation at $37^{\circ} \mathrm{C}$ for $15 \mathrm{~min}$. with penicillinase (Burroughs Wellcome) at a concentration of 1 in 100 before the polymorphs were ruptured and the bacteria enumerated. The rapid destruction of the surviving gonococci by the antibiotic shows that the persisting organisms were extracellular and that the failure to kill all the gonococci was due to a relative inability to phagocytose the bacteria. This finding does not

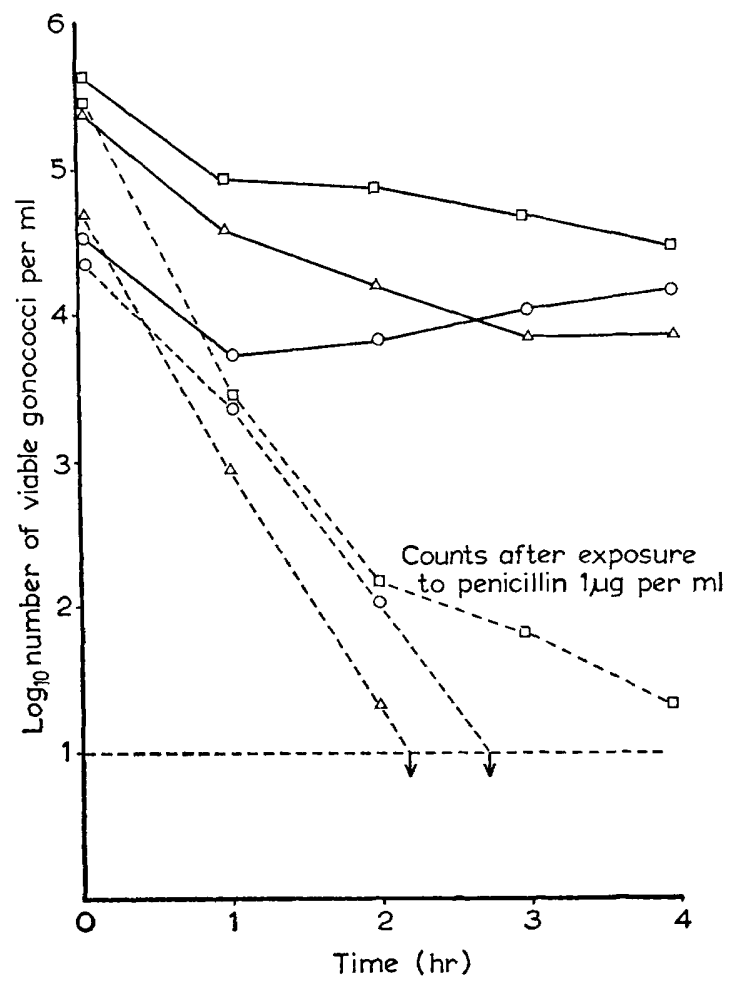

FIG. 2.-The survival rates of three freshly isolated strains of $N$. gonorrhoeae after phagocytosis by human polymorphs in vitro, and the effect of exposing the cell-associated gonococci to penicillin. Each line represents the average of three experiments. Gonococci multiplied slowly in the mixture of medium 199 with 10 per cent. heat-inactivated serum that was used to suspend the polymorphs. $\triangle-\triangle$ strain G9; $\square][]$ strain G11; $\bigcirc-O$ strain G34; $\triangle \cdots \triangle$ strain G9 after exposure to penicillin; $\square$ - - - $\square$ strain G11 after exposure to penicillin; $\bigcirc$... $\bigcirc$ strain G34 after exposure to penicillin.

explain the pathogenicity of $N$. gonorrhoeae, because in three experiments with the non-pathogenic Neisseria pharyngis flava (NCTC4590) the number of bacteria killed at $1 \mathrm{hr}$ was again only 80-85 per cent.

\section{The effect of polymorph cationic proteins on gonococci}

The preparations of cationic proteins were free from contamination with ribonucleic acid, lysozyme, acid phosphatase and $\beta$-glucuronidase. At a concentration of $5 \mu \mathrm{g}$ per $\mathrm{ml}$, both human and guinea-pig cationic proteins rapidly destroyed $1 \times 10^{6}$ Escherichia coli strain WF96 suspended in $0.05 \mathrm{M}$ 


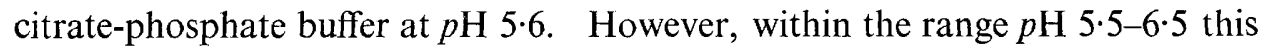
buffer was found to be lethal for gonococci. The same was found with other buffers, viz, acetate, bicarbonate, phosphate, tris and the zwitterionic buffers aces, ada, bes, mes and pipes (B.D.H. Ltd). Gonococci were not killed by

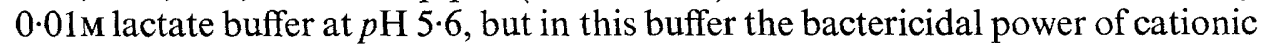
proteins was reduced. The same effect was seen when cationic nuclear histones were tested; their bactericidal action was greater in citrate-phosphate than in lactate buffer (Hirsch, 1958). To counteract this effect the concentration of cationic proteins was increased from $5 \mu \mathrm{g}$ per $\mathrm{ml}$ to $50 \mu \mathrm{g}$ per $\mathrm{ml}$.

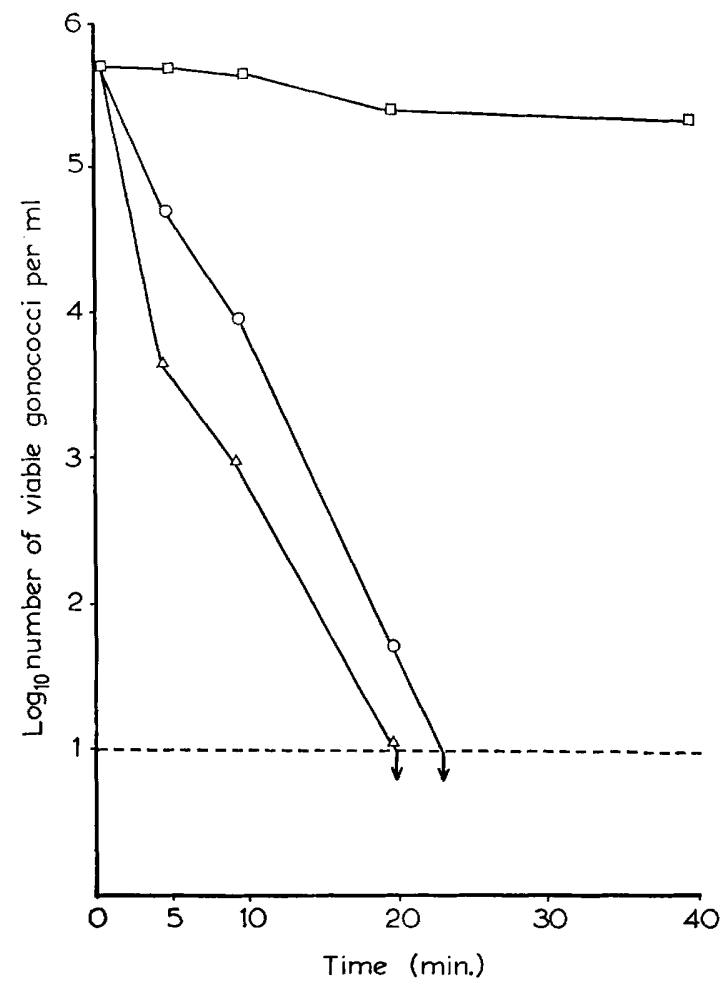

FIG. 3.-The bactericidal effect of cationic proteins from human and guinea-pig polymorph granules tested at a concentration of $50 \mu \mathrm{g}$ per $\mathrm{ml}$ on $N$. gonorrhoeae strain G11 suspended in $0.01 \mathrm{M}$ lactate buffer at $p \mathbf{H} 5.6$. Test strain in the presence of: $\triangle \longrightarrow \Delta$ guinea-pig cationic protein; $\bigcirc-\bigcirc$ human cationic protein; and $\square-\square$ buffer alone (control).

The bactericidal effects of cationic proteins on the three strains of $N$. gonorrhoeae are shown in figs. 3, 4 and 5; each line represents the average of three experiments. In the experiments with strains G11 and G34 (figs. 3 and 4), cationic proteins from human polymorph lysosomes destroyed 90 per cent. of $6 \times 10^{5}$ gonococci within $5 \mathrm{~min}$. Nevertheless, with guinea-pig cationic proteins the killing was ten-fold greater. Strain G9 was much more resistant to the bactericidal action of cationic proteins (fig. 5), but again the guinea-pig preparation destroyed more gonococci. 


\section{DiscusSION}

Suggestions that Neisseria gonorrhoeae and N. meningitidis survive within polymorphs have been made without citing evidence (Scherp, 1955; Smith, 1968), but the supposition is supported by the regular observation that in stained smears of infected material intracellular neisseriae appear morphologically intact. However, Roberts (1967) has convincingly demonstrated that

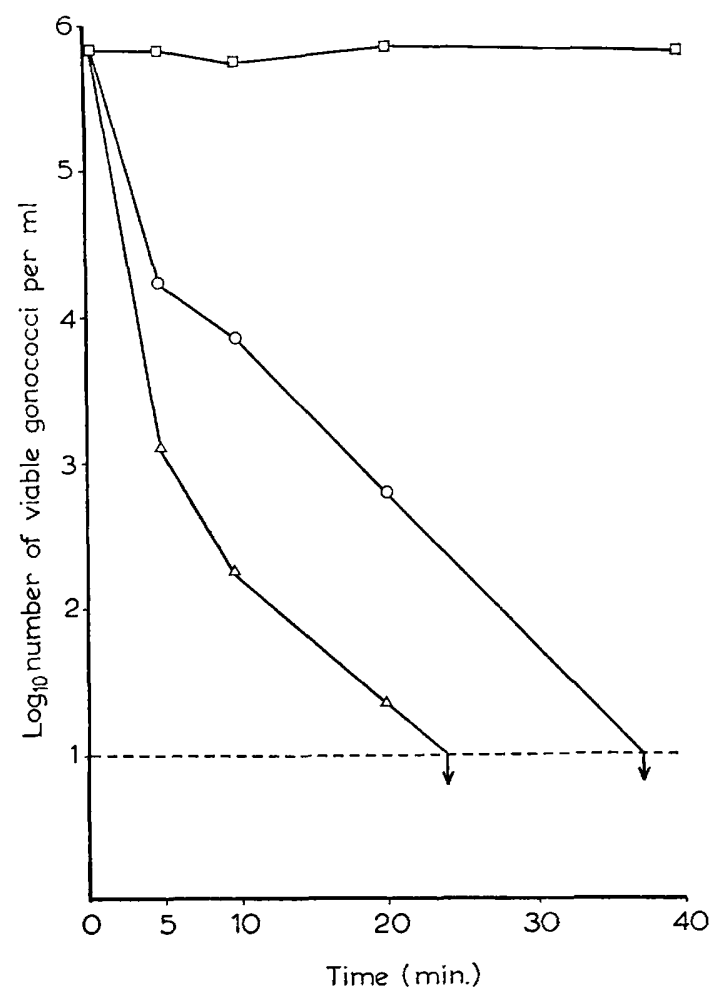

FIG. 4.-The bactericidal effect of cationic proteins from human and guinea-pig polymorph granules tested at a concentration of $50 \mu \mathrm{g}$ per $\mathrm{ml}$ on $N$. gonorrhoeae strain $\mathrm{G} 34$ suspended in $0.01 \mathrm{M}$ lactate buffer at $p \mathrm{H} 5 \cdot 6$. Test strain in the presence of: $\triangle \longrightarrow \triangle$ guinea-pig cationic protein; $\bigcirc-O$ human cationic protein; and $\square] \square$ buffer alone (control).

rabbit polymorphs destroy meningococci and, in the experiments presented here, gonococci were rapidly killed in guinea-pig polymorphs. Moreover, human polymorphs were found to be capable of killing all three strains of $N$. gonorrhoeae tested, although the half-life of the human polymorphassociated gonococci was some $25 \mathrm{~min}$. compared with 5-10 min. in the studies with guinea-pig polymorphs. The number of gonococci killed at I hr was 80 per cent. with human polymorphs and 99 per cent. with the guineapig cells.

The survival of 20 per cent. of the challenge dose of gonococci within human polymorphs could explain the pathogenicity of $N$. gonorrhoeae. Nevertheless, 
the failure of human polymorphs to kill all the gonococci might be due to the experimental conditions. When an almost identical technique was used to determine the ability of human polymorphs to kill Staphylococcus aureus, only 50 per cent. of the cell-associated bacteria were destroyed and, surprisingly, there was no difference in this respect between the survival of supposedly virulent and avirulent strains (Craig and Suter, 1966). The fact that penicillin destroyed the persisting cell-associated gonococci indicates that the survivors,

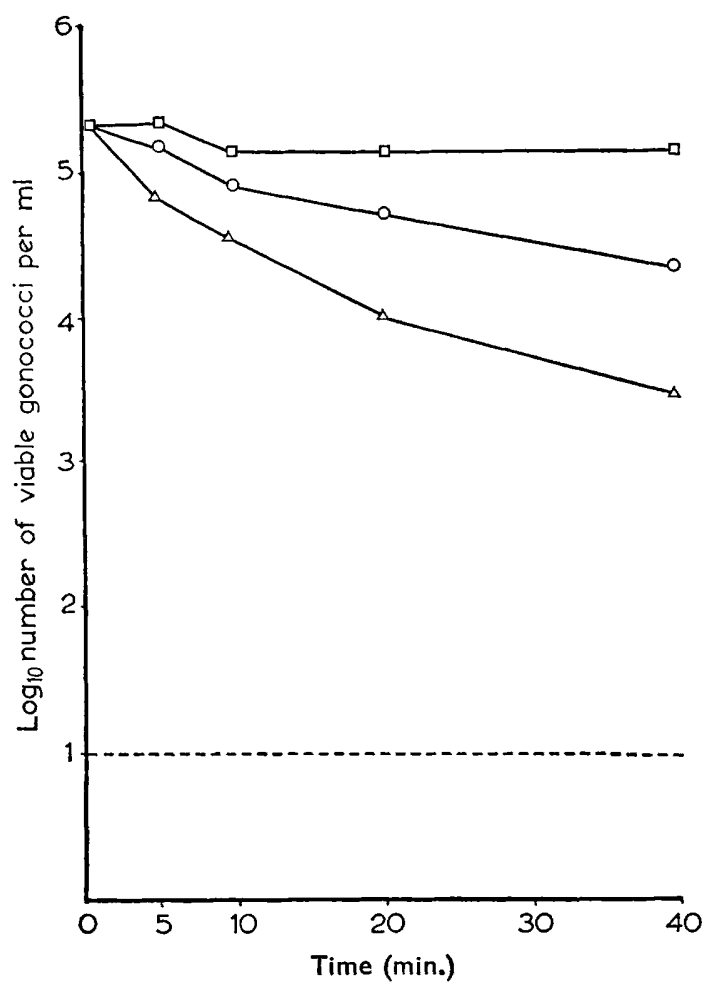

FIG. 5.-The bactericidal effect of cationic proteins from human and guinea-pig polymorph granules tested at a concentration of $50 \mu \mathrm{g}$ per $\mathrm{ml}$ on $N$. gonorrhoeae strain G9 suspended in $0.01 \mathrm{~m}$ lactate buffer at $p H$ 5.6. Test strain in the presence of: $\triangle-\triangle$ guinea-pig cationic protein; $\bigcirc-0$ human cationic protein; and $\square-\square$ buffer alone (control).

though adherent to the polymorphs or to traces of dextran remaining on the cells, were not in fact phagocytosed. Presumably polymorphs are impermeable to penicillin since staphylococci phagocytosed by polymorphs obtained from children with chronic granulomatous disease survive exposure to 100 units of penicillin for $24 \mathrm{hr}$ (Holmes et al., 1966).

My results contradict the early conclusions of Spink and Keefer (1937), who added gonococci to the washed cells from whole blood suspended in saline and recovered live bacteria after incubation of the mixture for $15 \mathrm{~min}$. Because phagocytosis was apparent in stained smears, Spink and Keefer concluded that the polymorphs had little or no killing action on gonococci. However, in 
similar experiments, but with improved suspending media and greater concentrations of polymorphs, large numbers of Staph. aureus, Staph. albus, Escherichia coli and Pseudomonas aeruginosa were destroyed by the polymorphs, although viable bacteria remained even after incubation for $1 \mathrm{hr}$ (Cohn and Morse, 1959; McRipley and Sbarra, 1967). Thus it could be that some gonococci were killed in the experiments of Spink and Keefer.

Lysosomal cationic proteins rapidly destroy gonococci in vitro and may constitute a possible mechanism for the killing action of both human and guineapig polymorphs on $N$. gonorrhoeae. There is some evidence that cationic proteins attack gonococci in vivo because intracellular gonococci in smears of urethral pus can be stained with alkaline-fast green and this indicates that they have become coated with cationic substances (Dr J. K. Spitznagel, personal communication). Although purified cationic proteins from polymorph lysosomes can destroy a wide range of pathogenic bacteria in vitro (Zeya and Spitznagel, 1966), the role of cationic proteins in the killing action of polymorphs has not been established. The fact that strain G9, which was partially resistant to cationic proteins in vitro, was destroyed by polymorphs at the same rate as the more sensitive strains suggests that other bactericidal mechanisms act on gonococci within the polymorphs. Because part of the preparation of human cationic protein was insoluble (see Methods) it might be argued that a fraction active against gonococci was discarded or that the preparation was partly denatured during alcohol precipitation. Obviously the quantitative difference between the bactericidal action of human and guinea-pig cationic proteins on gonococci requires confirmation.

The results presented here strongly suggest that man's susceptibility to gonorrhoea is not explained simply by the survival of gonococci in human polymorphs. Nevertheless, it may be that even virulent gonococci lose an antiphagocytic factor on growth in vitro as has been shown for Brucella abortus (Smith and Fitzgeorge, 1964) and that the failure to demonstrate resistance of the gonococci in these tests was misleading. There is some evidence that gonococci in urethral pus obtained from infected volunteers were more virulent than the parent culture used to initiate the infection in these volunteers (Mahoney et al., 1946). It is clearly desirable to investigate the activity of polymorphs and of cationic proteins on gonococci grown in vivo, but this still awaits the development of a model gonococcal infection.

\section{SUMMARY}

The fate of three freshly isolated strains of $N$. gonorrhoeae following phagocytosis by human or guinea-pig polymorphs was studied in vitro. Less than 1 per cent. of gonococci phagocytosed by the guinea-pig cells survived at 100 min., but some 20 per cent. of gonococci associated with the human polymorphs were not killed even after $3 \mathrm{hr}$. The persisting gonococci were destroyed when the polymorphs were exposed to penicillin and this indicates that the surviving bacteria lay outside the polymorph membrane.

Cationic proteins prepared by fractional ethanol precipitation of acid extracts of the granules from human and guinea-pig polymorphs rapidly 
destroyed gonococci in vitro and, presumably, are partly responsible for the ability of polymorphs to kill gonococci.

Although these findings require confirmation in studies with gonococci grown in vivo, they strongly suggest that man's susceptibility to gonorrhoea is not explained simply by the survival of gonococci in polymorphs.

I wish to thank Michael E. Ward for supplying strains G9 and G34 of Neisseria gonorhoeae and for advising on the techniques used for the culture of gonococci.

\section{REFERENCES}

Amies, C. R., and Garabedian, M. . 1967. Br. J. Vener. Dis., 43, 137.

Bessey, O. A., Lowry, D. H., AND Brock, 1946. J. Biol. Chem., 164, 321.

M. J.

Chodrrker, W. B., Bock, G. N., AND 1968. J. Lab. Clin. Med., 71, 9. Vaughan, J. H.

Cohn, Z. A., ANd Morse, S. I. $\quad$. $\quad$. 1959. J. Exp. Med., 110, 419.

CRaIG, C. P., AND Suter, E.. ～. . 1966. J. Immun., 97, 287.

Dische, Z., AND Swartz, K. ～. . 1937. Mikrochim. Acta, 2, 13.

Hill, Justina H.. . . . . 1944. Amer. J. Syph. Gonorrhoea Vener. Dis.,

HiRsCH, J. G. . . . . . 1958. J. Exp. Med., 108, 925.

Holmes, Beulah, Quie, P. G., Wind- 1966. Nature, Lond., 210, 1131. horst, Dorothy B., Pollara, B., AND Good, R. A.

Kellogg, D. S., Peacock, W. L., Deacon，1963. J. Bact., 85, 1274. W. E., Brown, L., AND PIRKLe, C. I.

Lowry, O. H., Rosebrough, N. J., Farr, 1951. J. Biol. Chem., 193, 265.

A. L., AND RANDALl, R. J.

Mahoney, J. F., van Slyke, C. J., 1946. Amer. J. Syph. Gonorrhea Vener. Dis., Cutler, J. C., AND Blum, H. L. $30,1$.

MCRIPLEY, R. J., ANd Sbarra, A. J. 1967. J. Bact., 94, 1417.

Martin, S. P., ANd Green, R. . . . 1958. Meth. Med. Res., 7, 136.

ROBERTS, R. B. . $\quad$. $\quad$. $\quad$. $\quad$. 1967. J. Exp. Med., 126, 795.

SCHERP, H. W. . $\quad$. $\quad$. $\quad$. 1955. A. Rev. Bact., 9, 319.

Shugar, D. . . . . . . . 1952. Biochim. biophys. Acta, 8, 302.

SMITH, H. . $\quad$. $\quad$. . . . . . 1968. Bact. Rev., 32, 164.

Smith, H., and Fitzgeorge, R. B. 1964. Br. J. Exp. Path., 45, 174.

SPInk, W. W., AND KeEfER, C. S. . $\quad$. 1937. J. Clin. Invest., 16, 169.

Talalay, P., Fishman, W. H., and 1946. J. Biol. Chem., 166, 757. Huggins, C.

Torrey, J. C. . . . . . . 1908. J. Med. Res., 13, 347.

ZeYA, H. I., AND SPITZNAGel, J. K. $\quad$. 1966. J. Bact., 91, 755. , " " " $\quad$. 1968. J. Exp. Med., 127, 927. 